\title{
Ideological Grounds for Settlement of Inter-Ethnic Relations in Modern Russia: Competition of Ideas and Ideology of Humanism
}

\author{
Anna Sergeevna Frolova1 \\ Anatoly Vladimirovich Lubsky² \\ Oxana Yuryevna Posukhova ${ }^{3}$ \\ Anton Vladimirovich Serikov ${ }^{4}$ \\ Yury Grigorievich Volkov 5 \\ ${ }^{1}$ Southern Federal University, Rostov-on-Don, Russian Federation \\ 2Southern Federal University, Rostov-on-Don, Russian Federation \\ ${ }^{3}$ Southern Federal University, Rostov-on-Don, Russian Federation \\ ${ }^{4}$ Southern Federal University, Rostov-on-Don, Russian Federation \\ ${ }^{5}$ Southern Federal University, Rostov-on-Don, Russian Federation \\ Email: frannser@gmail.com
}

Doi:10.5901/mjss.2015.v6n4s4p58

\section{Abstract}

This article demonstrates that modern Russia is facing the necessity to find ideological guidelines for further development, which will provide an opportunity to consolidate multi-national and multi-confessional population, build constructive dialogue of cultures, and develop common civic identity in line with the system of ideological, moral and cultural values of any nations residing in the territory of Russia. The author states that such ideology shall allow the representatives of various nations to hold a constructive dialogue in the comprehensible language of humanism while preserving cultural sensitivities and mental peculiarities. The article analyzes the modern state of ideological space of Russia, characterized by the competition of ideas and contradictions between the opposing systems of values and ideas. It has been shown that to relax tensions in the interethnic relations, build an effective and constructive dialogue, to be more precise - a polylogue, of cultures shall be possible only by assigning a specific meaning to the social development, based on clear and coherent ideological system accepted by the majority. In the author's opinion, the ideology of humanism has the highest potential in this respect.

Keywords: ideology, ideological policy, inter-ethnic relations, competition of ideas, humanism, humanism ideology, ideological space.

\section{Introduction}

The Russian community has to find consolidating ideological grounds, which will enable to determine the further vector for the development of the entire society, provide robustness and stability, become the basis for safeguarding the security of the country's ideological space and contribute to the settlement of complex and conflicting inter-ethnic relations, forming in the course of interaction of multiple cultures, confessions and systems of values. Such ideology will not be rigid, dogmatic totalitarian system, it should not be enshrined statutorily, but should pervade the entire social, sociocultural and economic policies, be objectified and find its direct expression in the particular social practices. Russia needs an ideology determining the development of moral, political, economic, social and even family living environment of the Russian community. At the same time the ideology shall be comprehensible and close to all nations of the Russian Federation, it shall serve as an integrating rather than disintegrating principle in the community.

\section{Literature Review}

One can record actualization of ideological discourse in the modern scientific thought. More and more attention is paid to the reconsideration of the role of the ideological factors and the meaning of the ideological process. The interrelation between ideology and political, economic, social, moral and other processes is revealed by such researchers as Slavoj Žižek (Žižek, 1999), Viacheslav Kuznetsov (Kuznetsov, 2008), Ulrich Matz (Matz, 1992). 
In the context of our work the views on the essence of ideology and, in particular, the ideology of humanism according to Y.G. Volkov, who writes that the ideological version of the world is a kind of social project. Ideology embodies the pursuance of an ideal, striving to build a more perfect world based on the fundamental ideas and understanding of the principles of the world order (Volkov, 2014).

The ethnicity concerns have also received a deep fundamental development in the investigative thought, which is stipulated by the global trends associated with the aggravation of inter-ethnic relations, proclaimed crisis and lack of multiculturalism policy, as well as the trends in religious and ethnic revival. The works of such authors as: Harold J. Abramson (Abramson, 1976), Fredrik Barth (Barth, 1969), Ernest Gellner (Gellner, 1991), Sherrow O. Pinder (Pinder, 2012) should be specially noted.

Such researchers as J. Rothschild (Rothschild, 1991), W. Sollors (Sollors, 1989), J. Haas (Haas \& Shaffir, 1979), D. Horowitz (Horowitz, 1985), S. Verba, K. L. Schlozman, H. Brady and N.H. Nie (Verba, et al., 1993) pay their attention to the issues of effective of policies and conflict prevention in the field of inter-ethnic relations, as well as the effective integration.

Also it is worth emphasizing the researchers who focus on the problem of finding a common national idea that can unite the community and ensure its stability and development. One should mention I. Neumann (Neumann, 1996), V. Bunce (Bunce, 2005), Yu.S. Oganisian (Oganisian, 2007) in this respect.

\section{Findings and Discussion}

While recognizing the necessity and the paramount importance of human freedoms and, in particular, freedom of thought, it is undeniable that the community stands in the imperative need of theoretically elaborated integrating ideology. In this sense, we appeal to the approach that defines the ideology through its positive impact as a frame of reference aimed at combining public and private interests, at forming axiological and regulatory consensus in the community (Volkov, 2014).

The ideological version of the world is a kind of social project. The ideology embodies the pursuance of an ideal, striving to build a more perfect world based on the fundamental ideas and understanding of the principles of the world order. The ideology performs functions of forecasting and planning for social development strategy.

In the conditions of deideologization of the Russian community the processes have evolved that led in some cases to stagnation and even to degradation of the moral, political, economic, family living environment and other spheres of society.

The ideological confrontation, being a struggle between different values expressed in an effort to interpret them (Rtskhiladze, Vekua, 2010), continues now not only between Russia and other major world powers, but also within the country itself.

Many researchers state that since 1989 the loss of intellectual initiative by the state authorities legitimately supported by the civic society structures in the daily lives of millions of children, teenagers, mature and elderly people has led to complete loss of awareness of common national goal, the meaning of life, it has twisted the ideals, values, traditions and customs of the nations of Russia (Kuznetsov, 2008).

The loss of integrating ideology and the lack of spiritual grounds for unity became a huge upheaval to the society, which did not provoke, but contributed to social, economic, political stagnation and made it impossible to radically change the situation in the future without the development of a new ideological base.

The problem of finding an integrated common civic identity is now ever more pressing. "The citizens of modern Russia are experiencing serious problems with the collective identity - generally speaking, there is hardly anything that brings them together: they have neither common ideology, nor common goals and interests, although in recent years a hope appeared as to the possibility of forming "a new common identity" - the Russian one" (Gorshkov, 2007). The uncertainty and often incomprehensiveness for ordinary consciousness of attempts to create a common civic, national identity leads to the fact that alternative forms of identity - ethnic, confessional, various local identities, etc. are brought to the forefront. This often results in an exacerbation and strife of inter-ethnic relations, the growth of nationalist sentiment.

In the current conditions the various ideological constructs exploiting cultural, confessional and ethnic differences between the citizens of Russia, appealing to the archetypes of the collective unconscious and the opposition "friend or foe" are gaining momentum. To a larger extent, this situation affects the south of Russia and the North Caucasus. This is precisely where the greatest concentration of fundamentally differing cultures is achieved. This is precisely the point where the clash of different ideologies takes place, competition of ideas manifests itself most acutely and the battle for the minds of the population goes on.

According to the national and confessional composition the North Caucasian region is a very heterogeneous territory populated by many ethnic groups. Some of them are quite numerous; others are represented by several 
hundreds of people. Many of them have their own language; while others have lost it or merged into larger language families. Some nations belong to the autochthonous peoples of the Caucasus, while others have moved to this territory quite recently. With regard to the above, all the nations living in the Caucasus have their cultural and mental peculiarities. The Caucasus has a rich history and spiritual heritage. However in the recent times the trends have been observed in the public consciousness of the Russians toward formation of the image of the socially and economically under-developed, wild, aggressive, even "barbaric" Caucasus, being a volatile area, a hotbed of extremism and separatism.

The reasons for the instability in the south of Russia are of complex character. Here the role is played by both external and internal, endogenous factors, the growth of politicized ethnicity (including vigorous activity of various "ethnoparties"), and inter-ethnic tensions, as well as often poorly controlled migration processes, and specific forms of the "religious revival".

Against the background of the lack of an integrated ideology, and the disintegration of the socio-cultural space during the previous twenty years, the ethno-conflict processes in the North Caucasus have considerably marginalized the public consciousness and led to the increased social insecurity, anomia, and the growing influence of the ideas of separatism, nationalism and extremism in the mass consciousness.

An enormous competition in the struggle for the public consciousness contributes to destabilization of the situation in the country. It is felt particularly acute in the south of Russia, where the multiple cultures and religions are intertwined. Thus, even people who profess the same religion are heterogeneous in their beliefs, as they are committed to significantly different currents. Devout Muslims who profess traditional Islam constitute the major part of the Caucasian population. Sufism is one of the most organized and influential religious movements in the republics of the Caucasus.

However, there are alongside, for example, the followers of foreign fundamentalist Salafi movement in the Caucasus, as well. This movement is known to have originated in the early stages of the Muslim world development and advocates for the revival of the ideas of the original, "pure" Islam of Prophet Muhammad's times. Its key provisions have obtained the ideological expression in the radical Wahhabism, calling for jihad against all who disagree with the Wahhabi interpretation of Islam. Today, radical ideas of Wahhabism spread throughout the world, and at the end of the 80-90-ies of the last century they penetrated into Russia, particularly in the Caucasus.

The nations of Russia, in particular of its southern regions, are now undergoing a critical period of reconsideration of their religious and historical traditions. The ideological and spiritual cultural movements competing with each other, for which it is hard to find mutual understanding, are crystallizing inside the communities.

Historically, peace in the North Caucasus was supported by means of a complex system of inter-ethnic "checks and balances": cross-national, intertribal alliances, adats and customs. In XIX-XX centuries the traditional way of life and traditional social institutions of the Caucasus were partly blurring. All this has resulted in the situation where the old norms and values, the system of checks began to retreat into the background, losing their significance. Whereas new regulatory mechanisms based on the action of official state institutions and respect for the rights and freedoms of the individual have not fully formed yet.

As a result, the split of the world outlook has occurred, and it was mainly in the minds of young people. The rudiments of the former, the traditional perception of the world force them to perceive the people of other nationality as "outsiders" and "enemies", but the authority of traditional institutions and conflict settlement, such as councils of elders, customary law, have not had proper weight already.

In the recent decades, dilution of the Soviet identity was taking place, but a new, all-Russian identity was not formed. Studies of the Institute of Sociology of the Russian Academy of Sciences showed that about $53 \%$ of young adherents of Islam in the North Caucasus do not identify themselves with the Russian Federation. (Gorshkov, Sheregi, 2010).

In these circumstances, a sign of nationality becomes the main criterion of self-identification. Hence, the ideologies of nationalism in various forms are growing and gaining momentum. They include speculations concerning the spiritual rebirth of the nation and ethnocentrism, militant nationalism and religious extremism.

Alongside with the positive processes in the socio-economic development of the South of Russia the situation in several regions of the Southern Federal District and the North Caucasian Federal District is characterized by increasing inter-ethnic tensions, inefficiency and corruption of the regional authorities, the pendency of territorial disputes, high unemployment, especially among young people. There is still growing Slavophobia, Islamophobia and anti-Caucasian sentiments in these federal districts, an outflow of Slavic population is observed, not only from the republics of the North Caucasus, but also from some areas in Stavropol and Krasnodar territories.

Currently there is no clear understanding of what should be the basis of Russian common national identity and become an axiological, spiritual foundation of the country's development. However, to date, the attempts to revive traditional values and Orthodoxy are undertaken, building identities on the basis of precisely these constructs. The inner 
space of Russia becomes a zone for deployment of axiological and ideological competition at this stage.

Within several recent years, active attempts have been undertaken to form axiological and ideological constructs and identification based on the combination of pre-Soviet, Soviet elements and modernization in the revival of the role of patriotism, Orthodoxy, maximum centralization of state power, etc.

Naturally, in the domestic space the attempts to introduce and "engraft" these values face stiff competition of ideas and the penetration of competing structures from the outside. The "Western" system of values, which is now identified with the "global" one, acts as the most complicated "rival". Aggressive expansion of the Western system of values associated primarily with the ideals of the market economy, liberalism, individualism, rationalism and democratic political system is carried out nowadays.

However, it is important in this respect to understand the current trends, consisting in the fact that the values of modern Western ideologies such as neo-liberalism, neo-conservatism and even social democracy, have almost exhausted their potential by the beginning of the new century. The Western society based on the principles of the material wealth priority over the spiritual one became deadlocked. It is required to create a new ideology, "which would take into account the positive aspects of ideologies of both capitalist and socialist countries, as well as the values and ideologies of Eastern and Western cultures. When creating a new ideology, it is necessary to consider also the global trends in the formation of the global network society. (Frolova and Volkov, 2015).

One of the prominent modern scholars dealing with the problem of ideology, V.N.Kuznetsov wrote: "Russian uniting, statehood and patriotic ideology (ideology of consolidation, national ideology, uniting ideology, Russian ideology, "Russianizm") is an understood and accepted by people forming, relatively stable articulated set of personal, public, state and civilizational goals, ideals, values, interests that contribute to every person in the formation and constructive functioning of historical memory, the Russian dream and the meaning of life through a respectful dialogue, the culture of the world and culture of patriotism; in achieving decent quality and well-being, reliable security by this person; in the interpretation of the past, comprehension of the present and in understanding of the future" (Kuznetsov, 2008).

It is necessary to develop an ideology capable to combine the values of all the numerous nations living in the territory of Russia. Such an ideology should allow the representatives of different nations to hold a constructive dialogue in the comprehensible language of humanism while preserving cultural sensitivities and mental peculiarities.

People are in urgent need to fill their life with new meanings, values, because it is known that if a person's life does not have any meaning, sooner or later the person will fall into frustration, apathy, lose any desire to move forward and develop. Often people try to fill the emptiness formed as a result of lacking unified ideology with pseudo values of the consumer society or destructive ideologies.

The ideologies dividing us, and first of all, the ideology of nationalism, are appealing to the cultural and historical traditions and notions about the ethno-national state as a carrier of these traditions. It is based on the idea of ethnopolitical mobilization, titular state-forming ethnic group and justification of its particular way in history. However, if we pay attention to the complex and heterogeneous ideological space of the South of Russia, where ideological and axiological systems of many nations and cultures intertwine and interact, we will be able to understand that the basic cultural and moral values and attitudes existing in the region not only contradict to the provisions of the ideology of humanism, but yet can easily be woven into its context, that is, they can be integrated into it.

In recent years, active attempts have been made to create a national idea for Russia, to construct a common civic identity and develop a consolidating ideology possessing the potential for the development of society based on the system of values shared in the mass consciousness. All this is happening against the background of the integrative Eurasian rhetoric that gains momentum.

Nowadays stability, integration, conservative values, centrism in politics is the basis for the formation of the allRussian ideology. "Centrism is directly related to the integrative ideology it differs from many political movements precisely in its commitment to the real process, the desire to avoid extremes. The main ideological postulate of centrism lies in recognition of the relativity of the order, organization and spontaneity, self-organization" (Yurchenko, 2012). If supporters of the "left-wing" views emphasize only the paternalistic role of the state and proclaim the paramount need to protect the poorest strata of the population, and the right-wing liberal approach is focused on the survival of the strongest, the centrist position is aimed at considering both of these approaches and suggests the principle of providing internal political stability and integration as the basic conditions of social security, which can be provided only by means of maintaining the balance of interests between different social groups.

However, the traditional ideologies, which can be defined in a linear left-right dimension, have lost their relevance and are unable to endue the contemporary Russian society with the sense. Today, as the researchers note, the modernist ideologies "in their pure form" cannot be distinguished in the ideological space, numerous "ideological hybrids" are becoming more widespread (Korovnikova, 2011). 
Multi-national and multi-confessional Russian society offers the potential opportunity for the formation of the spiritual heritage of the world significance. It is this that can provide the basis for a common idea, around which the ideology will be built. But the main thing here is not to overreact and not to go into the Russian national messiahship. The ideas that the Russian nation is the God-bearing people, the people of the Messiah (Maslin, 1992) are rooted in the distant past, but now it is often possible to hear precisely such ideas in the rhetoric of the influential circles. Unfortunately, the attempts to introduce the values of spirituality and integration are interpreted and introduced in the mass consciousness just as the ideas of messiahship and God's chosenness.

Currently attempts are made to take spirituality, which is understood exclusively as the religious spirituality, or to be more precise the orthodox spirituality, as the basis of the national idea.

Various researchers state that there is every indication of the resacralization of religion (Orthodoxy) in modern Russia, which is essentially a response to the destruction of religious institutions (Baghdasaryan, Sulakshin, 2011). Nowadays, when a real competition of ideas unfolds in the mass consciousness, the searching for meanings is actualized and the importance of religion (not only of the Orthodox, but also of other religions of the nations of Russia, and Islam in particular) increases, such situation may lead to further polarization of different groups of the population according to the ethnicity and confession, it may result in increasing feeling of aloofness in the nations and simple people who do not identify themselves with Orthodoxy.

The Russian community can develop only on the basis of the consolidating ideology, integrative Russian common national identity, taking into account the diversity of cultures, beliefs and ethnicities that are included in the overall process of social creation and preservation of the integrity and identity of the Russian state - nation (Volkov, 2014). At the same time, such an ideology cannot be the result of artificial constructing and imposing "from above", it must follow from a variety of public interests.

The category of justice, increasingly appearing in the rhetoric of the ideologues, is now also laid down into the basis of a national idea. The national idea must essentially be the idea of a reasonable and equitable society. And it is rather consistent with the attitudes of the mass consciousness - the idea of social justice, equal rights for all dominates in the public mood (from 32\% to 49\% depending on the worldview orientations) (Gorshkov, 2012).

A humanistic project that puts the disclosure of the person's creative nature and the creation of a society of social humanism at the top of priorities seems to be most promising at this moment. Building a humanistic society requires the fundamental reorientation of the development of all processes, structures and spheres of the community.

According to Immanuel Wallerstein, "The issue before us is more polarized: either egaliberty or neither liberty nor equality; either a true effort to be inclusive of everyone or a retreat into a deeply partitioned world, a kind of global apartheid system" (Wallerstein, 2003). To achieve such world-system where both liberty and equality will exist is possible with reorientation of the entire society on the spirituality and creative development of a person.

\section{Concluding Remarks}

The contemporary ideological space of Russia is characterized by its heterogeneity, lack of consolidation and tension. At present, almost no one doubts that the country needs an integrating ideology. Active attempts to form a national idea and common civic identity are undertaken; however there are many contradictions in this sphere today. There is no clearly articulated ideological construct yet, and continuous competition of ideas is carried on, the struggle for the minds of the population is fought in the ideological space. Radically different political views, religious beliefs, values and ideas compete in the mass consciousness. Particularly acute struggle is manifested in the ethnic and confessional sphere, as the Russian society is heterogeneous precisely on these grounds, and in the absence of a single national idea it fails to find here enough areas of common interests to overcome tensions. The ideology of humanism is directed towards the future, it appeals primarily to a person, regardless of his or her ethnic origin. It formulates the goal - the creation of such social conditions under which a person could not only exist normally, but also would develop his or her abilities to the full extent. The ideology of humanism implies the primacy of the interests of the individual, his or her spiritual selfimprovement and development, the entire artistic and creative personal fulfillment. Such an ideology would resolve numerous contradictions of the ideological space in Russia and eliminate the destructive manifestations of competition of ideas, having established a constructive dialogue, and more likely - the polylogue of ideas, instead.

\section{Acknowledgement}

This article was financially supported by the grant of the Russian Science Foundation No. 15-18-00122 "Institutional practices and value policy in the sphere of harmonization of interethnic relations in the economically developed countries 
with complex ethnic and cultural structure: comparative analysis and modeling of implementation in the Russian context".

\section{References}

Abramson, H.J. (1976) On Sociology of Ethnicity and Social Change: A Model of Rootedness and Rootlessness (p.p. 43-59) // Economic and Social Research Institute, Economic and Social Review, Vol. 8, No.1.

Barth F. (ed.) (1969) Ethnic Groups and Boundaries. The Social Organization of Culture Difference.- Bergen: Norwegian University Press

Bunce, V. (2005) The National Idea: Imperial Legacies and Post - Communist Parthways in Eastern Europe // Eastern European Politics and Societies, Vol.19, №3.

Frolova, A.S. \& Volkov, Y.G. (2015) Ideological Dimension of the Network Society and the Ideology of Global Humanism. Mediterranean Journal of Social Sciences. Vol 6, No 3. S 3.

Haas, J., Shaffir, W. (1979) Symbolic Interaction Theory//Shaping identity in Canadian Society.- Scatborough.

Horowitz, D. (1985) Ethnic Groups in Conflict.- Berkley. Cat. Etc.

Neumann, I. (1996) Russia and the Idea of Europe: a Study in Identity and International Relations. London: Routledge.

Pinder, S. O. (2012) The Politics of Race and Ethnicity in the United States/ Americanization, De-Americanization, and Racialized Ethnic Groups. Publisher: Palgrave Macmillan

Rothschild, J. (1991) Ethnopolitics: A Conceptual Framework. - New York: Columbia University Press

Sollors, W. (1989) The Invention of ethnicity.- New York: Oxford University press.

Verba, S., Schlozman, K. L., Brady, H. \& Nie N.H. Race, Ethnicity and Political Resources: Participation in the United States // British Journal of Political Science. Vol. 23, No. 4 (Oct., 1993).

Baghdasaryan, V.E., Sulakshin, S.S. (2011). Vlastnaya ideynaya transformatsya: Istoricheskiy opyt i tipologiya [Ideological Transformation of Authorities: Historic Experience And Typology].- Moscow: Nauchnyy Expert, P. 258.

Wallerstein, I. (2003) The End of the World As We Know It: Social Science for the Twenty-First Century. (p. 136). Moscow: Logos,

Volkov, Yu.G. (2000) Manifest gumanizma. (Ideologiya I gymanisticheskoye buduschee Rossii) [The Manifesto of Humanism. (Ideology and Humanist Future of Russia)].- Moscow: ANO RJ Social and Humanitarian Knowledge, 2000.

Volkov, Yu.G. (2014) Kreativnyy klass - alternative politicheskomu radikalizmu [Creative class - an Alternative to Political Radicalism] /I Sociological studies. No. 7

Volkov, Yu.G. (2014) Rossiyskoye obschestvo: sostoyanie I perspektivy ideologicheskoy sphery [Russian Society: State and Prospects of the Ideological Sphere] // Social and Humanitarian Knowledge. No. 2.

Gellner, E. (1991) Nations and Nationalism // Translated from English by T.V. Berdikova, M.K. Tyunkina; Ed. Krupnik, I.I.- Moscow: Progress.

Gorshkov, M.K. (Ed.) (2007) Rossiyskaya identichnost v sotsiologicheskom izmerenii [Russian Identity in the Sociological Dimension]. Analytical report. Russian Academy of Science. Institute of Sociology.- Moscow

Gorshkov, M.K. (Ed.) (2013) O chem mechtayut rossiyane: ideal I realnost [What do the Russians Dream about: Ideal and Reality] (p. 51). Moscow: Ves Mir

Gorshkov, M.K., Sheregi, F.E. (2010) Molodezh Rossii: sotsiologicheskyy portret [The Youth of Russia: Sociological Portrait] (2nd ed.).Moscow: TsSPiM.

Žižek, C. (1999) The Sublime Object of Ideology.- Moscow: Khudozhestvenyy Zhurnal

Korovnikova, N.A. (2011) Natsionalnaya idea: ideologicheskyy aspect [National Idea: Ideological aspect] // National Idea of Russia. (p. 199) (Moscow, November 12, 2010)

Kuznetsov, V.N. (2008) Sotsiologiya ideologii [Sociology of ideology].- Moscow: Kniga i Business.

Maslin M.A. (comp.) (1992) Russkaia ideya [Russian Idea](p. 243).- Moscow: Nauka.

Matz, U. (1992) Ideology as a determinant of the policy in the era of the Modern [Text] // Polis. 1992. № 1.

Oganisian, Yu.S. (Ed.) (2007) Nationalnaya idea: strany, narody, sotsiumy. [National idea: countries, nations, social media].- Moscow: IS RAS.

Rtskhiladze, G, Vekua, G. (2010) Postsovetskoye prostranstvo kak object geopoliticheskoy ekspansii: ideologicheskyy aspect [PostSoviet Space as an Object of Geopolitical Expansion: Ideological Aspect // Central Asia and Caucasus. Issue No. 2. Vol. 13.

Yurchenko, M.V. (2012) Politico-ideologicheskie trendy v informatsionnom prostranstve sovremennoy Rossii: teoreticheskie konstruktsii i kontsepty [Political and Ideological Trends in the Information Space of Modern Russia: Theoretical Constructions and Concepts /I Human. Community. Management. No. 1. 